\title{
Some Implications of the EU Rail Transport Policy on Rail Business Environment in CEE Countries
}

\author{
Olga Nežerenko \\ Tallinn School of Economics and Business Administration, \\ Tallinn University of Technology \\ Akadeemia tee 3 , \\ Tallinn 12618, Estonia \\ E-mail: olga.nezerenko@gmail.com
}

Ott Koppel

Department of Logistics and Transport,

Faculty of Civil Engineering,

Tallinn University of Technology

Ehitajate tee 5 ,

Tallinn 19086, Estonia

E-mail: ott.koppel@ttu.ee

Abstract: The development of rail transport is the key to the integral development of the entire European transport system. In 2010, consultations were started to discuss the proposal of the European Commission for merging various EU directives relating to railway transport. In 2011, the European Transport White Paper was published; the paper lays down the transport policy for the current decade with a perspective up until the years 2030/2050. The principles of the White Paper are compliant with the general ideas of the Commission. Both of these documents see the strengthening of supervision at the national level as the key issue for improving the competitiveness of the rail sector; require the separation of ownership and using the first best infrastructure pricing solutions. The authors find that the following questions must be answered in order to implement these ideas: 1) how to allocate supervisory functions between the state and infrastructure manager; 2) which would be the best way for realising the unbundling of rail activities; 3) how can the sustainability of railways be ensured while using marginal cost pricing in the situation where formal transport policy does not allow state support for rail transport. The authors seek answers to these questions by comparing the situation in the Nordic and Baltic countries, as these two groups of countries illustrate two diametrically different approaches to the possible solutions. 
Olga Nežerenko, Ott Koppel

Keywords: access charging, infrastructure investments, rail transport, transport policy

\section{Introduction}

The transport system has always been playing an important role for the European Union and its member countries. The effective and integrated transportation links are the most important prerequisite for ensuring coordinated work of the EU's Single market. The transport sector accounts for about 5 per cent of the EU's GDP and it is considered to be an important tool against unemployment, as it directly employs around 10 million people (EU, 2011). The sustainable development of the EU transport system needs a set of appropriate law regulations. Economic, social and environmental dimensions of the transport policy are set up by the 2011 White Paper (White Paper, 2011), which stems from the earlier White Paper approved in 2001 (White Paper, 2001). A vision for a competitive and sustainable transport system needs considerable collaboration of all allied groups, whose activity predetermine the viability of the intention to create a single European transport area. The Baltic Sea strategy holds an important place among the EU strategies stressing the integration of various interest groups. It is an initiative of the EU, aiming to find solutions to the main bottlenecks of the region hindering the development of the area. The Baltic Sea strategy consists of two parts: a strategy document and an action plan accompanying the strategy paper (Communication from..., 2009). These documents define four strategic areas-environmental sustainability, prosperity, accessibility and attractiveness, safety and security.

Based on these areas, the action plan for the strategy is divided into 15 political fields, each of which contains particular projects that will be implemented within the framework of the action plan. From the point of view of the present article the most important one is political area No. 11 of the Baltic Sea strategy-To improve internal and external transport links. Among the flagship projects listed in the horizontal dimension of the vertical dimension "accessibility and attractiveness" (Complete the agreed priority transport infrastructures, Northern Dimension Partnership on Transport and Logistics, Develop the Baltic Motorways of the Seas Network, Shorter Plane Routes, Cooperate for Smarter Transport) should be pointed out prioritised investments in transport infrastructure, for example the Rail Baltic project. Meanwhile, the overall experience of certain countries (first and foremost in the Baltic states) in the implementation of international projects is so far insignificant. The competition is still a stumbling block, forcing 
the countries to concentrate purely on the national transport market and to forget about developing the coherence between the national transport networks and to neglect building partner relations (Nežerenko, 2009). This is illustrated by the delays in implementing the Rail Baltic project mentioned above.

The EU development-oriented documents described above stress the importance of preferring the environmentally sustainable modes of transport, mostly waterways and railways, both from transport and regional policy aspects. The task of this article is to investigate some of the problems that have to be resolved in the CEE countries of the Baltic Sea region and Poland in order to achieve the targets laid down in the Transport White Paper and the Baltic Sea Strategy of the European Union. In the following part some of the postulates of the EU's transport policy that are significant from the point of view of achieving the set goals will be described.

\section{Background}

The process of rail market liberalisation started in 1991. The legislation is based on a distinction between infrastructure managers who run the network and the railway companies that use it for transporting passengers or goods. Different organisational entities must be set up for transport operations on the one hand and infrastructure management on the other. Essential functions such as allocation of rail capacity (the train paths that companies need to be able to operate trains on the network), infrastructure charging and licensing must be separated from the operation of transport services and performed in a neutral fashion to give new rail operators fair access to the market. The process of opening up the railway services market to cross-border competition is presented below. During the past decade, the following packages of railway directives were adopted:

- "The first railway package" of 2001, which enabled rail operators to have access to the trans-European network on a non-discriminatory basis, implemented a common licensing of the railway operators and guaranteed operators' rights for the use of railway infrastructure capacity;

- "The second railway package" of 2004. In the framework of this package the set of measures to revitalise railway transport was adopted. The rail freight market was fully opened to competition from the $1^{\text {st }}$ of January 2007. Due to the implementation of the first two packages the decline in railway sector was temporarily stopped by 2007 ; 
- "The third railway package" of 2007 aimed on completing the European regulatory framework for the rail transport, including the introduction of the European train driver license and strengthening rail passengers' rights. The package provided for opening up the international passenger transport market by the $1^{\text {st }}$ of January 2010 .

Despite the fact that the packages of liberalisation's measures are implemented (excluding market opening to domestic passenger rail services, which is going to be realised by the year 2012) there are still problems that need to be resolved, for instance:

- Inadequate regulatory oversight by national authorities, often with insufficient independence, competences and powers;

- A low level of competition due to market access conditions which are not sufficiently precise and therefore still biased in favour of the incumbents;

- Low levels of public and private investment, as the quality of infrastructure is declining in many Member States because of insufficient funding, investment in railway services becomes less attractive both for incumbent and new operators.

The European Commission set up proposals for adopting a new directive (Communication from..., 2010), which is focused on the resolving the abovementioned bottlenecks of the Single European Railway Area. The main solutions mentioned in the proposal are:

- In order to monitor competition situation on the rail transport service market, an independent surveillance body not subject to any of the ministries must be established;

- In addition to railway infrastructure managers, also transport undertakings or even third persons possessing infrastructure necessary for the provision of rail transport service can be natural monopolies;

- Rail infrastructure user fee must be based on the first best solution, i.e. marginal cost pricing with the possibility to apply mark-ups in the condition that market can bear it.

Thus, the proposal of the European Commission focuses on three main areas: supervision in the field of competition in railway transport, defining of companies in market dominant position and explaining them their obligations, and railway infrastructure access pricing. 


\section{Method and Data}

The authors are of the opinion that in the set of the circumstances mentioned above, the following questions need to be answered:

- How to allocate supervisory functions between the state and infrastructure manager if the organisational structure of rail transport has been made compliant with the EU legislation;

- Which would be the best way for realising both the horizontal and vertical separation of rail transport in compliance with the EU requirements;

- How can the financing of railway undertakings be ensured whilst using marginal cost pricing in the situation where formal transport policy does not allow supporting rail freight transport from the state budget?

The scope of the data used for the purposes of this article was defined on the basis of the following considerations. The Baltic Sea region includes the Baltic countries (Estonia, Latvia, and Lithuania), Denmark, Finland, Sweden, northern Germany, northern Poland, and part of Russia's Northwestern Federal District. Considering the importance of the Baltic Sea region in the transport links of Northern Europe, the EU has involved also Iceland, Norway and Belarus in implementing its Baltic Sea strategy. CIA World Factbook (2011) defines Estonia, Latvia, Lithuania, Poland, Belarus and Germany as CEE countries, whereas Norway, Finland, Sweden, Denmark and Iceland are defined as Nordic countries. Thus, the group of selected

Figure 1. Selected countries

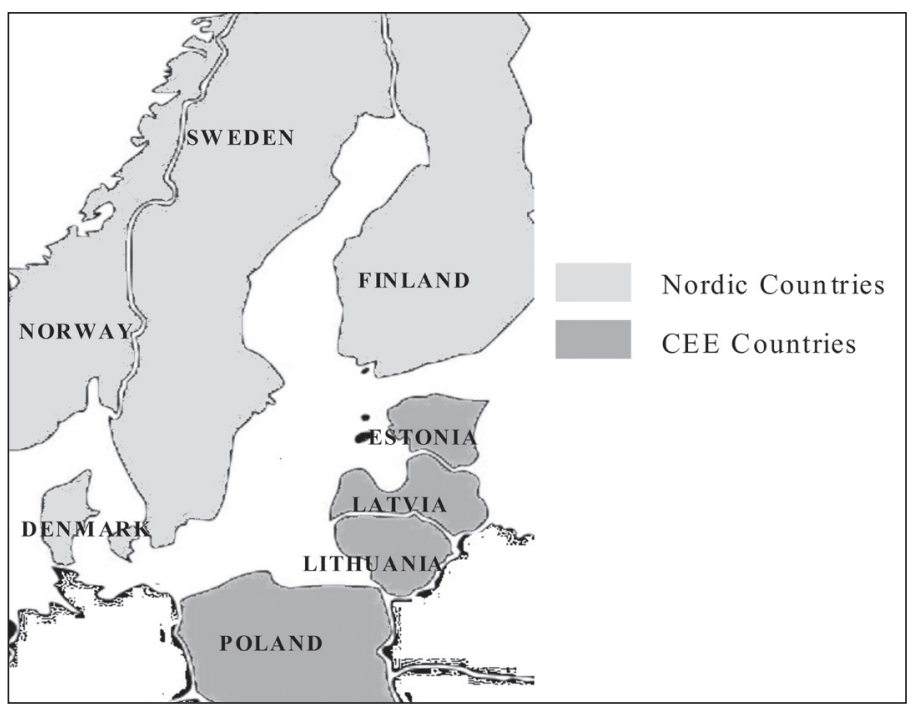

Source: Authors' illustration countries in this article includes the Baltic States and Poland from CEE countries, and the Nordic countries (excl. Iceland). The geographical position of the countries is depicted in Figure 1.

The paper uses the comparative analysis method. 
The analysis is based on secondary source information provided by the railway infrastructure managers, rail transport undertakings of the region, national statistics authorities and international professional associations. In presenting conclusions and recommendations the specific features of rail transport in particular regions are taken into account: for example, in the Baltic States railway companies are mostly engaged in servicing transit freight originating from third countries.

\section{Study}

\subsection{Institutions}

According to Directives 2001/12/EC and 2001/14/EC of the EU, each member requires an independent regulatory body (though not necessarily of the government) whose task is to ensure a fair and non-discriminatory access to the rail network and services.

The regulators are usually established to carry out complex technical tasks which the government is unable or unwilling to do, partly because the government wishes to distance itself from responsibility for some decisions, but, having invested regulatory authorities with sometimes considerable powers which are more detailed and intrusive than any possessed by government over state-owned entities or industries, political or bureaucratic impatience or intolerance of that power sometimes takes over, and undue governmental pressure or interventions follow.

As a result, many countries are not able to completely withdraw from the elements of oligopoly or monopoly (see also below) in railway services - it is difficult for governments to give up control of their domestic railway sector and to abandon their basic rights in the formation of transport policy and oversight of railroad operators and service enterprises. Previously, a common idea that natural state monopoly on the market of railway services is a guarantee of the development of, at least, the railway infrastructure, has lost its relevance. Market liberalisation and the creation of independent institutions are the necessary prerequisites for the formation of long-term competitiveness of railways, including improving the quality of services provided by operators (Winsor, 2010).

The level of independence of national authorities can seriously vary within the EU because the current EU legislation requires regulators to be independent of the infrastructure manager, but not necessarily of government. Therefore, the regulatory bodies in Europe can be divided into three categories:

- special regulatory bodies; 
- regulatory bodies within a railway authority;

- regulatory bodies within a ministry.

While the model of the special regulatory body is the strongest form in terms of its powers and independence from the state and the infrastructure manager, regulatory bodies within a ministry can be considered the weakest form (IBM, 2011). Finland, Norway, Latvia and Sweden according to the presented classification have Regulatory Body within a Railway Authority. This model deals primarily with licences, safety and other railway-specific administrative tasks, although Finnish and Swedish railway sector are governed by the crosssectoral transport authority (Finnish Transport Safety Agency and Swedish Transport Agency, respectively). Denmark is the only one among the countries under consideration that has established a special Regulatory Body, whereas in Estonia and Lithuania such agencies have been established within the administrative area of governing ministries (see Fig. 2).

Figure 2. Organisation of regulatory bodies for rail transport in selected countries

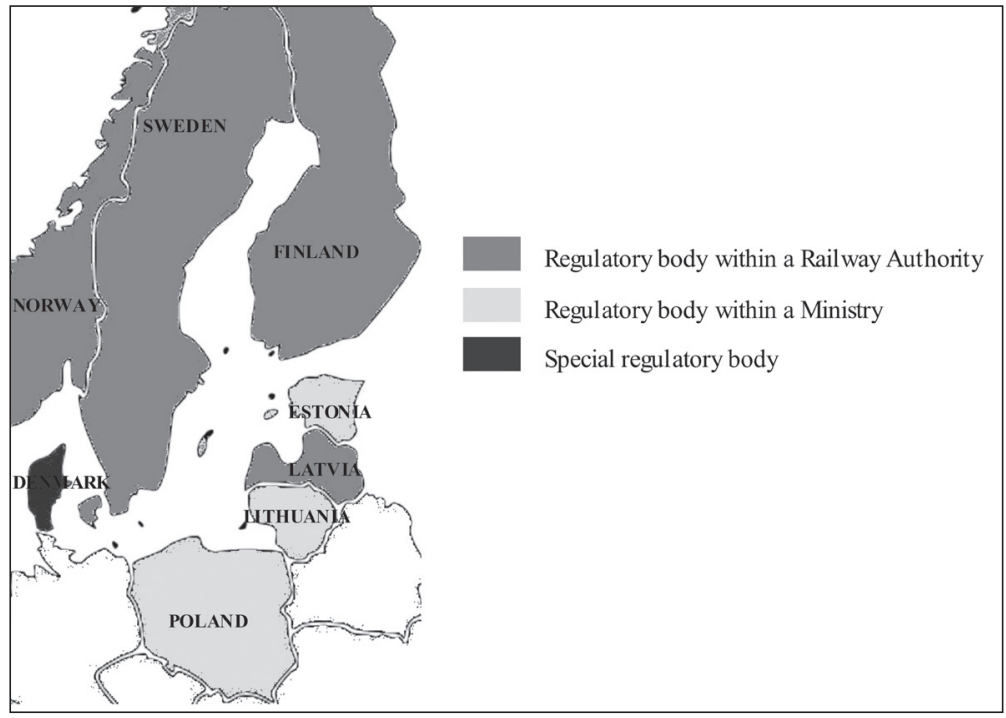

Source: IBM, 2011

A rail regulator independent of direct political control, with clearly specified powers and responsibilities and adequate resources, offers many advantages. It may offer the infrastructure manager the guarantee that the required level and quality of infrastructure will be consistent with the funding provided, and protect new entrants from arbitrary or discriminatory regulatory measures designed to protect the existing operator. Indeed, this degree of independence is even more 
important when there remains a major state-owned incumbent operator, and particularly when this operator is part of the same organisation as the infrastructure manager. Given the existence of such a regulator, it is doubtful whether the right of appeal to a separate competition authority is either necessary or helpful; of course, recourse to the courts on matters of process (rather than substance) should be possible. At the same time it is important that general competition authorities have a strong role in developing government policy for the railways, for example in relation to the structural organisation of the sector, not least in order to guard against the dangers of regulatory capture (ECMT, 2005).

Therefore, considering the positions expressed in the EU transport policy documents and related studies, it would be necessary to reorganise competition supervision both in CEE and most of the Nordic countries. Based on the Estonian example, such reorganisation should involve establishing an independent supervisory body dealing with competition in railway. The position of such agency in the hierarchy of Estonian state institutions should be similar to that of the Legal Chancellor or the Auditor General.

\subsection{Organisation of rail transport}

The issues and approaches to regulation are directly affected by vertical and horizontal separation (Thompson, 2009). Rail transport is a part of national economy from which it obtains its input and to which it gives its output. Therefore we cannot treat railway undertakings as subsystems of the system of rail transport in isolation from the context.

The most important sub-system of railway transport is the sub-system of railway infrastructure. Table 1 presents the parameters of the railway networks of the selected countries as of 2005 and in perspective until the year 2020. For historical reasons, these countries have two different track gauges, which is one of the factors hindering interregional cooperation. The table also indicates that there are no significant conventional and high-speed railway projects envisaged for the next decade (this does not include different routes for the Rail Baltic project).

Train traffic analysis for CEE and Nordic countries (see Fig. 3) shows that passenger trains prevail in most of the countries. This sets stricter requirements for the technical condition and safety of railway networks. There are also railway sections in the Baltic countries where the density of passenger trains is higher than the density of the freight trains but there are also many sections (e.g., Valga-Koidula in Estonia) for which under normal conditions exist no demand whatsoever. 
Figure 3. Traffic-mix in selected countries 2007

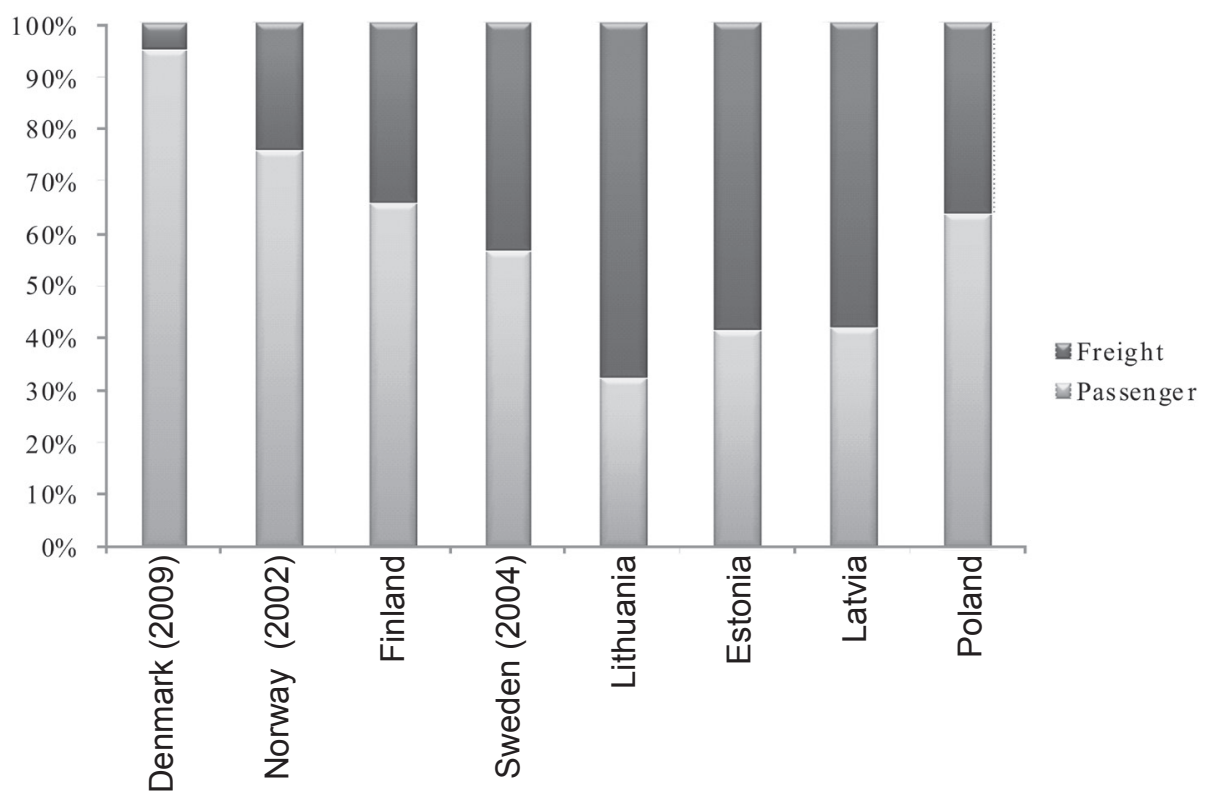

Source: UIC, 2008

Table 1. Length and link type of TEN-T railways in selected countries

\begin{tabular}{|c|c|c|c|c|}
\hline \multirow[t]{2}{*}{ Country } & \multirow[t]{2}{*}{ Type (track gauge) } & \multicolumn{3}{|c|}{ Length (km-s) } \\
\hline & & 2005 & 2013 & 2020 \\
\hline \multicolumn{5}{|c|}{ Nordic countries } \\
\hline Denmark & conventional $(1,435 \mathrm{~mm})$ & 928 & 928 & 944 \\
\hline Finland & conventional $(1,524 \mathrm{~mm})$ & 3,492 & 3,576 & 3,594 \\
\hline Norway & conventional $(1,435 \mathrm{~mm})$ & 4,087 & 4,159 & $N / A$ \\
\hline \multirow[t]{3}{*}{ Sweden } & conventional $(1,435 \mathrm{~mm})$ & 3,181 & 3,181 & 3,181 \\
\hline & high-speed $(1,435 \mathrm{~mm})$ & 1,600 & 1,600 & 1,600 \\
\hline & Total & 4,781 & 4,781 & 4,781 \\
\hline \multicolumn{5}{|c|}{ CEE countries } \\
\hline Estonia & conventional $(1,524 / 1,520)$ & 962 & 962 & 962 \\
\hline Latvia & conventional $(1,520 \mathrm{~mm})$ & 1,340 & 1,340 & 1,340 \\
\hline Lithuania & conventional $(1,520 / 1,435)$ & 933 & 1,036 & 1,036 \\
\hline \multirow[t]{3}{*}{ Poland } & conventional $(1,435 \mathrm{~mm})$ & 5,187 & 4,888 & 4,888 \\
\hline & high-speed $(1,435 \mathrm{~mm})$ & 0 & 337 & 337 \\
\hline & Total & 5,187 & 5,225 & 5,225 \\
\hline
\end{tabular}

Source: DG Mobility and Transport, 2011, and UIC, 2008 
Among the CEE countries under discussion, the share of rail passengers in the overall passenger turnover (incl. passenger cars) is the highest in Poland (6\% in 2009 ) and the lowest in Lithuania (1\%). This rate is considerably higher in the Nordic countries, reaching almost $10 \%$ in Denmark and Sweden.

In most of the countries, passenger transport by rail has not been affected by the economic crises as much as the other areas of economy, as there has occurred no significant reduction in rail passenger turnover (see Fig. 4).

Figure 4. Passenger turnover by rail in selected countries

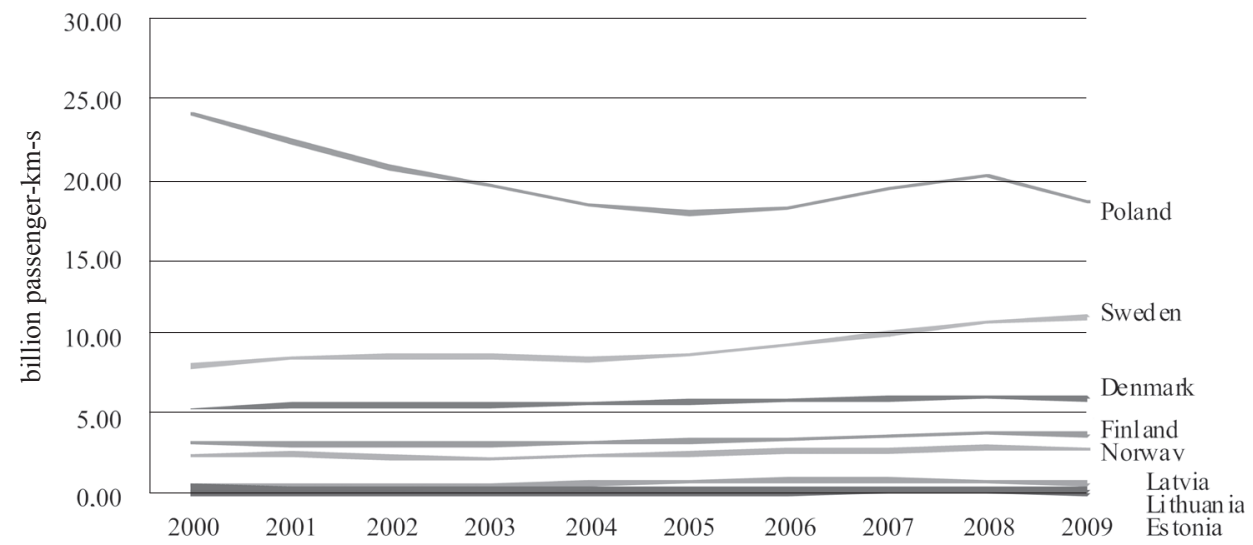

Source: EU, 2011

The share of rail transport in the overall freight turnover among the CEE countries of the Baltic Sea region has been the largest in Estonia (70\% in 2007) and the smallest in Poland (37\%). In the Nordic countries this indicator remains between 8 per cent (Denmark) and 34 per cent (Sweden) (EU, 2011).

During the economic crisis, a significant reduction of rail freight volume occurred in Poland and Estonia (see Fig. 5), whereas there was no such obvious reduction in the other countries under discussion. According to data provided by the Statistics Working Committee of the International Union of Railways (UIC) such reduction was of temporary nature, as rail freight volumes started to grow at the beginning of 2010 .

Meanwhile, leaving aside the Baltic countries, the share of rail transport in the freight turnover of the European Union has not reached the set target-15 per cent share by the year 2010 (European Transport..., 2001). In order to improve the situation, the European Commission has made among many of its proposals the proposal for the endorsement of a new railway directive that 
carries the idea of establishing a single European railway area. The main tool foreseen for achieving this objective is the unbundling of the currently vertically and horizontally integrated railway companies in order to ensure sufficient separation of railway infrastructure managers from freight and passenger transport undertakings. Such restructuring of railway companies is necessary for several reasons.

Figure 5. Freight turnover by rail in selected countries

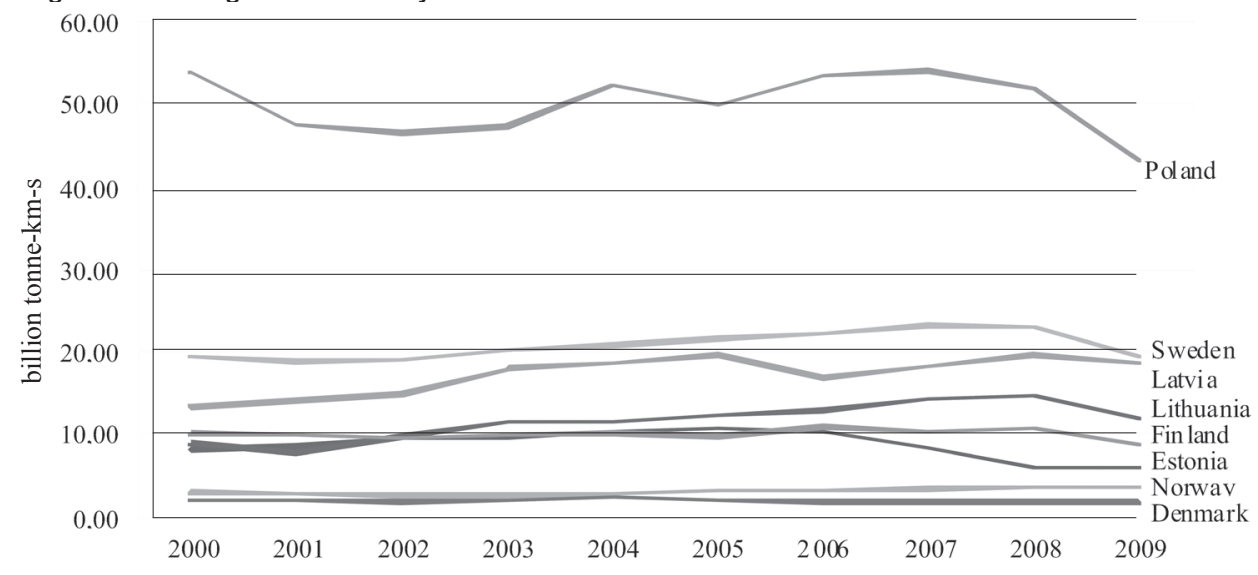

Source: EU, 2011

Firstly, infrastructure managers working in a regulated business environment must be separated from freight and passenger transport service providers working on competitive market so that the infrastructure managers would treat all freight and passenger transport operators (including those belonging to a same group of companies) equally. So the companies would have more trust, new companies could enter the market more easily and there would be more competition. All that could have positive influence on freight transport charges.

Secondly, such separation of railway companies would prevent subsidising freight transport service on the account of regulated infrastructure service provision (or vice versa-Authors'note), which could affect freight transport charges in a way that would prevent freight transport undertakings from coming to the market.

Thirdly, in case of separation, the infrastructure managers can focus on their main activity-provision of services ensuring access to infrastructure (Communication from ..., 2010).

There are several ways how to separate infrastructure managers from freight transport undertakings. 
1) Recording revenue, expenses, assets and liabilities separately for different activities, i.e. the so-called accounting separation;

2) Functional separation of infrastructure manager, passenger and freight transport undertakings, i.e. the independence of infrastructure managers in groups of companies is ensured (separate organisation, independent decision-making system, independence of management, right to determine investments into network and keeping of confidential information);

3) Legal separation of infrastructure managers, passenger and freight transport undertakings in the course of which a separate undertaking dealing with infrastructure management is established inside a group of companies.

4) Ownership separation - the most radical way of separation, meaning that a railway company must fully or partially give up its ownership in freight transport undertaking (Kukke, 2011).

In broad terms, railways are organised as Ministries, state-owned enterprises and as independent corporations (though some or all of the equity may be owned by the state) (Thompson, 2009). The degree of separation in rail transport sector extends in the Nordic and CEE countries from functional separation to a complete ownership separation of infrastructure and operations (RGL Forensics, 2009). Within the geographical scope of the paper, there is a full vertical and horizontal ownership separation in the areas of infrastructure and operations in the Nordic countries like Norway and Sweden. In CEE countries, that is in Estonia, Latvia, Lithuania and Poland, there is functional, legal and accounting separation (see Fig. 6) of various forms that will be analysed in the present article using the example of Estonian Railways.

Estonian Railways, Ltd (EVR) is according to the OSJD (2002) the main railway undertaking in Estonia. EVR was a vertically integrated freight transport railway that was also the owner of the largest public railway network in Estonia. In the years 2001-2007, private investors owned 66 per cent of EVR's share capital, whereas today 100 per cent of the company's shares are back in government ownership. On 14 January 2009 EVR split into two new companies: AS EVR Infra dealing with railway infrastructure management and AS EVR Cargo providing freight transport and rolling stock services. Similar vertical separation has taken place in Poland and Latvia.

At the end of November 2010, the European Commission initiated legal actions against 13 Member States, incl. Poland, in the European Court of Justice, claiming that these countries have not implemented the First Railway Package of 2001 at a sufficient level. The main complaints of the Commission are as follows: 
- The integration of infrastructure managers in the group of companies, the model selected by many countries, incl. CEE states in the Baltic, infringes the provisions of EU unbundling legislation.

- Member States do not ensure that their infrastructure charges pay sufficient attention to the market viability of individual market segments.

- There are no incentives for infrastructure managers to reduce costs and lower infrastructure charges.

- The regulatory authority does not have sufficient powers to conduct market polls (Deutsche Bahn, 2011).

The Government of the Republic of Estonia has passed a resolution about conducting the ownership separation of railway companies already in 2012 (see Fig. 7). The holding company Estonian Railways, Ltd was divided on 4 September 2012 into two separate companies, whereas the business name of Estonian Railways remains with the infrastructure manager AS EVR Infra.

Figure 6. Models of separation between operations and infrastructure in selected countries

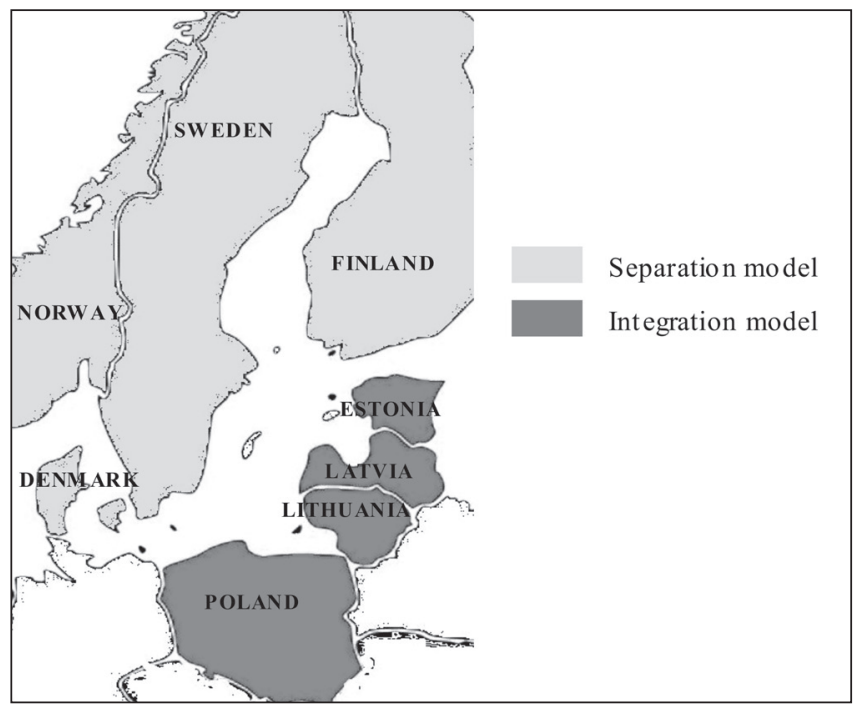

Source: IBM, 2011

Differently from Estonia, many European governments have stated publicly that their regulations were transposed in conformity with the Directives and are in line with the objectives of the railway packages. It has also been claimed that criticism can be levied as regards the Commission's procedures in that it is attempting to enforce its own ideas of regulatory legislation not by means 
of parliamentary legislative proceedings, but in the form of extensive legal interpretation (Deutsche Bahn, 2011).

Figure 7. Model of organising rail transport in Estonia considering EU regulations

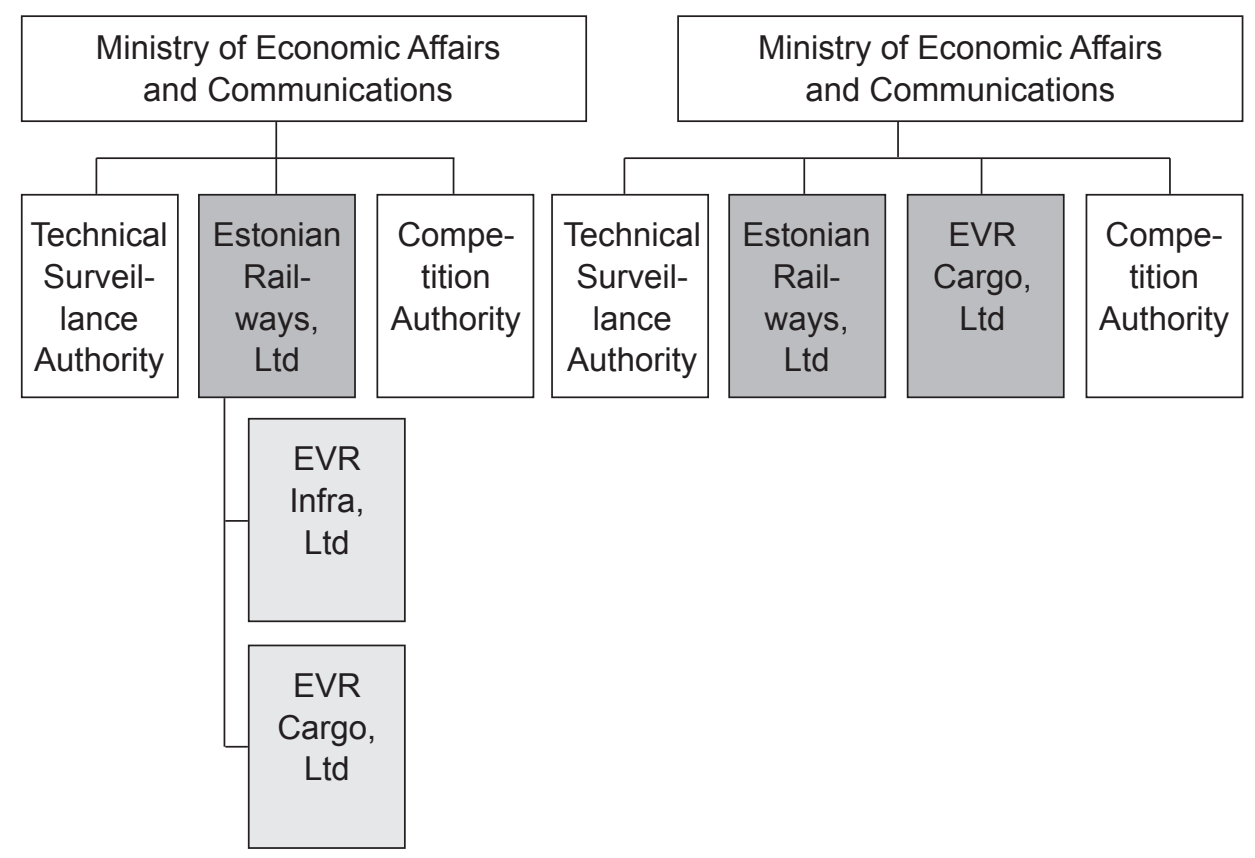

Source: Nežerenko and Koppel, 2012

The authors are of the opinion that this position is justified, as the Council of Ministers and the European Parliament had agreed that the first railway package was to grant the Member States a certain degree of freedom in transposition of the measures. This also refers in particular to the form of corporate structure, infrastructure charging and the decision on whether the incentive to reduce costs is to be designed as a performance regime, in the form of multiannual contracts or in some other way. Therefore, the reorganisation process in Estonia could prove to be unnecessary.

\subsection{Rail infrastructure charging issues}

In the previous section it was mentioned that the European Commission has complaints regarding infrastructure pricing mechanisms against many Member States. Therefore, the authors analyse the details of infrastructure pricing in the Nordic and Baltic countries. 
Pricing theory is based on the perfect market, that is a market where the supply and demand are always in balance. As any other goods market, the rail transport service market is not a perfect one-market failures occur. In the context of this study, market failures mainly manifest themselves in the form of natural monopolies. A natural monopoly is defined as an undertaking who owns essential facilities, such as an infrastructure or other, which other persons cannot duplicate or for whom it is economically inexpedient to duplicate, and the access to which is essential in order to operate on the goods market. In order to regulate the activities of undertakings in a dominant position, the state can use different price regulation methods (Baumstark \& Bonnafous, 1998).

In case of the best solution, a price is effective (optimal) when it equals both the marginal cost and consumer marginal surplus. Marginal cost is an extra cost incurred to produce a product or service unit, that is a change in total cost which equals a change in the volume of production by one output unit. Special methods for marginal cost pricing are: social marginal cost pricing (SMC); short-run marginal cost pricing (SRMC); short-run marginal social cost pricing (SRMSC); long-run marginal cost pricing (LRMC); long-run marginal social cost pricing (LRMSC); Ramsey pricing; cost-plus pricing $(\mathrm{MC}+$ ).

The typology of special methods of marginal cost calculation universal methodology is based on the fact that if the time horizon is sufficiently long, all infrastructure management costs are variable costs. According to literature, in the case of SRMC-method a price is effective if capacity is limited or excessive, and in the case of LRMC-method if the capacity and demand are exactly the same. In the case of SMC-methods, all transportation system costs, both regarding the consumer and society in general, are included in price formation (Koppel, 2006).

Maximum efficiency obtained by marginal cost pricing in sectors with increased returns, for example in railway infrastructure management, is a decisive conclusion contributed by the theory of welfare economics. However, this theoretical result presents a number of problems (Baumstark \& Bonnafous, 1998). The authors of this article find that such problems are manifested in the large investment need of railway infrastructure, competition for freight trains originating from third countries and cross-subsidising between freight and passenger transport taking place in the selected countries. Table 2 presents information about railway infrastructure pricing methods used in the countries under discussion. It can be seen that the Nordic countries use exclusively the marginal cost pricing method and the Baltic countries use the fully distributed costs (FDC) method. Finland can be considered a special case, as the Finnish 
infrastructure pricing method is based on the long-term marginal costs of the infrastructure.

Table 2. Use of pricing methods in selected countries

\begin{tabular}{|l|c|c|c|c|c|}
\hline \multicolumn{1}{|c|}{ Country } & Pricing & Two- or & \multicolumn{2}{c|}{ Charges per } \\
\cline { 4 - 6 } & principle & $\begin{array}{c}\text { Chulti-part } \\
\text { tariff }\end{array}$ & $\begin{array}{c}\text { gross tonne- } \\
\text { km }\end{array}$ & train-km & path-km \\
\hline Denmark & SRSMC+ & & & $V$ & \\
\hline Finland & LRSMC+ & & $V$ & & \\
\hline Sweden & SRSMC+ & & $V$ & & \\
\hline Norway & SRSMC+ & & $V($ freight $)$ & & \\
\hline Estonia & FDC & $V$ & $V$ & $V$ & \\
\hline Latvia & FDC & & & $V$ & \\
\hline Lithuania & FDC & $V$ & $V$ & $V$ & $V$ \\
\hline Poland & FDC & & & $V$ & $V$ \\
\hline
\end{tabular}

Note: SRSMC - short-run marginal social cost pricing, LRSMC - long-run marginal social cost pricing, FDC - fully distributed cost pricing.

Source: ECMT, 2005

Estonia has chosen to use two-part tariff method where the fixed component is theoretically meant for covering the costs related to train control. The external marginal cost of transport system is partially included in the railway infrastructure pricing model of all the Nordic countries, including costs such as those related to congestion, railway accidents or negative environmental impact (noise, vibration, air pollution) (see Table 3).

Table 3. Cost items included in variable infrastructure charges in selected countries

\begin{tabular}{|c|c|c|c|c|c|c|}
\hline \multirow[t]{2}{*}{ Country } & \multicolumn{6}{|l|}{ Cost items } \\
\hline & Maintenance & Renewals & $\begin{array}{l}\text { Traffic } \\
\text { management }\end{array}$ & Congestion & Accidents & $\begin{array}{l}\text { Environment } \\
\text { impacts }\end{array}$ \\
\hline Denmark & $V$ & & & $V$ & & \\
\hline Norway & $v$ & & & & $V$ & $v$ \\
\hline Sweden & $V$ & & & & $V$ & $v$ \\
\hline Finland & $V$ & $V$ & & & & $V$ \\
\hline Estonia & $V$ & $V$ & $V$ & & & \\
\hline Latvia & $V$ & $V$ & $V$ & & & \\
\hline Lithuania & $V$ & $V$ & $V$ & & & \\
\hline Poland & $V$ & $V$ & $V$ & & & \\
\hline
\end{tabular}

Source: ECMT, 2005

In the relevant literature (Baumstark \& Bonnafous, 1998) two main principles of railway infrastructure pricing have been mentioned. One of them involves relating pricing to the difficult question of covering the fixed costs which within 
the rail system, as many other networks, represent a large proportion of the total costs. The European Commission's proposal (Communication from..., 2010) sets the maximum of 35 per cent for direct costs to be included in infrastructure charge. It implies that the remaining part of the costs should be covered by the state budget. While this practice is prevailing in certain Member States (where railway freight share is around $10 \%$, this share focuses on containerised cargo, and subsidies to rail operations and infrastructure are significant), it is not the case in other Member States. For example, in the Baltic States (Lithuania, Latvia, and Estonia) infrastructure managers are not significantly subsidised by governments (see Fig. 8). They earn revenues from infra-structure charges to cover the needed investments in rail infrastructure, maintenance and development.

Figure 8. Target per cent of the total cost covered by infrastructure charges

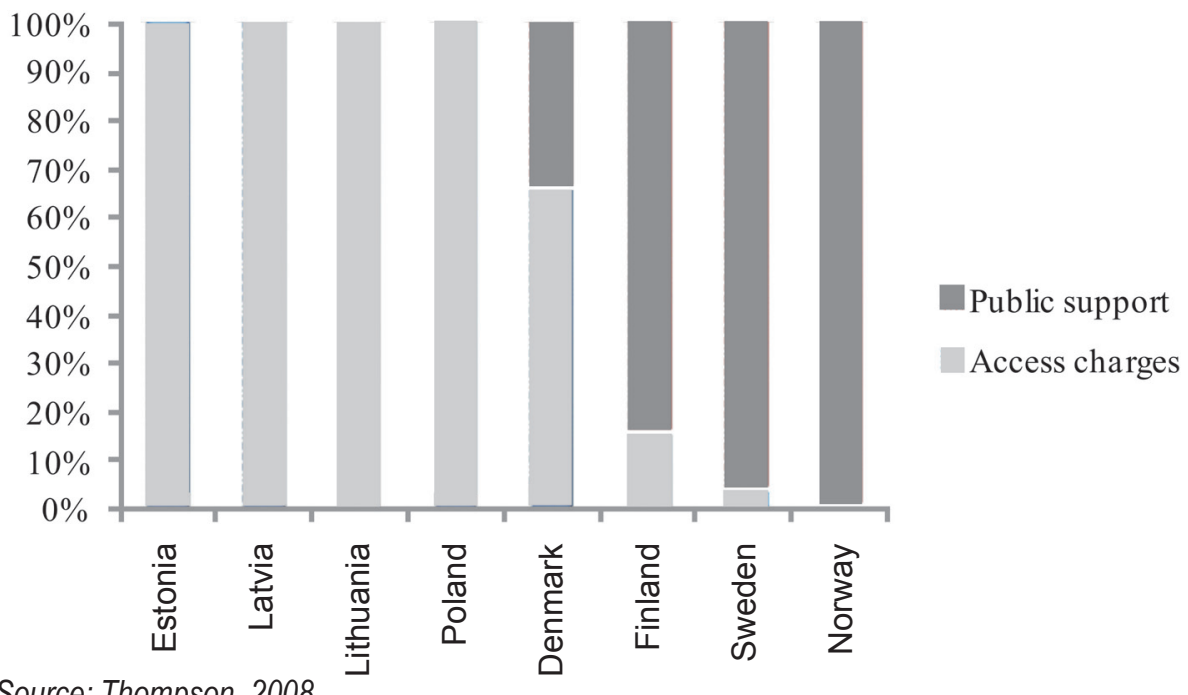

Source: Thompson, 2008

The railway undertakings of the Baltic countries can be characterised by a vast need for investment that would be necessary for implementing the projects and targets mentioned in the Transport White Paper and the Baltic Sea Strategy of the EU. It is also not certain whether the state budgets of these countries would have sufficient funds for financing railway infrastructure in the suggested volume.

The aforementioned is substantiated by the fact that the rail infrastructure investment and maintenance costs per one kilometre (see Tables 4 and 5) are substantially higher in the Nordic countries than in the selected CEE countries (apart from Lithuania). 
Table 4. Investments per $\mathrm{km}$ of track in selected countries (current prices and exchange rates, million euros)

\begin{tabular}{|l|c|c|c|c|c|c|c|c|c|c|c|}
\hline Country & $\mathbf{2 0 0 0}$ & $\mathbf{2 0 0 1}$ & $\mathbf{2 0 0 2}$ & $\mathbf{2 0 0 3}$ & $\mathbf{2 0 0 4}$ & $\mathbf{2 0 0 5}$ & $\mathbf{2 0 0 6}$ & $\mathbf{2 0 0 7}$ & $\mathbf{2 0 0 8}$ & $\mathbf{2 0 0 9}$ & $\mathbf{2 0 1 0}$ \\
\hline Nordic countries \\
\hline Norway & 86.8 & 47.7 & 46.5 & 49.1 & 54.4 & 47.3 & 63.1 & 68.9 & 69.9 & 87.2 & n.a. \\
\hline Finland & 39.8 & 34.8 & 38.4 & 47.0 & 57.2 & 49.1 & 39.6 & 35.8 & 55.2 & 57.1 & 61.3 \\
\hline Sweden & 53.6 & 52.7 & 73.9 & 67.4 & 71.9 & 77.5 & 82.8 & 102.2 & 119.6 & 118.4 & 128.7 \\
\hline Denmark & 204.5 & 166.0 & 172.7 & 121.5 & 122.5 & 91.0 & 67.3 & 87.7 & 141.0 & 134.8 & 149.8 \\
\hline
\end{tabular}

Source: ITF, 2012

Table 5. Maintenance expenditure per km of track in selected countries (current prices and exchange rates), million euros)

\begin{tabular}{|}
\begin{tabular}{|c|c|c|c|c|c|c|c|c|c|c|}
\hline Country & $\mathbf{2 0 0 0}$ & $\mathbf{2 0 0 1}$ & $\mathbf{2 0 0 2}$ & $\mathbf{2 0 0 3}$ & $\mathbf{2 0 0 4}$ & $\mathbf{2 0 0 5}$ & $\mathbf{2 0 0 6}$ & $\mathbf{2 0 0 7}$ & $\mathbf{2 0 0 8}$ & $\mathbf{2 0 0 9}$ \\
\hline Nordic countries \\
\hline Norway & 80.4 & 91.5 & 102.7 & 95.3 & 86.6 & 88.1 & 98.8 & 101.3 & 108.8 & 130.1 \\
\hline Finland & 19.6 & 21.3 & 23.0 & 23.4 & 27.1 & 27.3 & 26.4 & 28.3 & 30.4 & 33.1 \\
\hline Sweden & 32.0 & 31.1 & 40.2 & 48.2 & 70.2 & 51.4 & 53.4 & 55.7 & 54.2 & 53.0 \\
\hline Denmark & n.a. & n.a. & n.a. & n.a. & n.a. & n.a. & n.a. & n.a. & n.a. & n.a. \\
\hline CEE countries \\
\hline Estonia & 22.6 & 18.9 & 15.1 & 12.6 & 11.9 & 13.6 & 18.5 & 20.8 & n.a. & n.a. \\
\hline Latvia & 20.7 & 21.7 & 23.5 & 18.6 & 24.5 & 26.6 & 31.0 & 39.3 & 55.9 & 73.2 \\
\hline Lithuania & 25.0 & 29.1 & 42.2 & 52.2 & 53.6 & 59.5 & 59.5 & 64.9 & 65.0 & 93.8 \\
\hline Poland & 2.6 & 2.2 & 1.9 & 3.3 & 3.8 & 4.2 & 3.4 & 5.2 & 1.8 & 7.9 \\
\hline
\end{tabular}
\end{tabular}

Source: ITF, 2012

In order to achieve the targets set in the EU transport policy (high-quality transport connections), the total investments into infrastructure and maintenance costs in the CEE countries should increase 5-20 times. It is highly probable that such situation cannot be achieved without subsidies from the state budget (as is the case in Norway, Sweden and Poland) or the EU structural funds (the Baltic countries) (ECMT, 2005).

Therefore, the second principle of railway infrastructure pricing is based on the acknowledgement that rail infrastructure pricing cannot be separated from investment choices. The example of Estonian Railways (former EVR Infra, Ltd) shows that in order to satisfy the investment need of a company through access fee's capital cost component based on the full infrastructure costs (considering that the weighted average useful life of railway infrastructure components is 
ca 30 years), a cumulative sum of more than half a million euros should be covered annually. As Estonian Railways is a business undertaking, the so-called reasonable business profit should be added. The Estonian legislation stipulates that such profit is the product of weighted average capital cost and the residual value of non-current assets. It has also been considered that according to the accounting rules applicable in Estonia, the investments made with the assistance of the EU structural funds are not depreciated.

Rail freight traffic in the Baltic States is essentially devoted to shipping exports of Russian commodities to seaports for further exports (i.e. these are reexports) or to shipping commodities from Russia into the Russian enclave of Kaliningrad (i.e. these are re-imports of the Russian Federation). This unique case requires special treatment. It does not make sense to use public funds from the EU Member States to effectively lower track access charges in this particular case, since this would be a transfer of public funds to undertakings from a third country.

Figure 9. Average annual investments of Estonian Railways in railway infrastructure and sources of funding

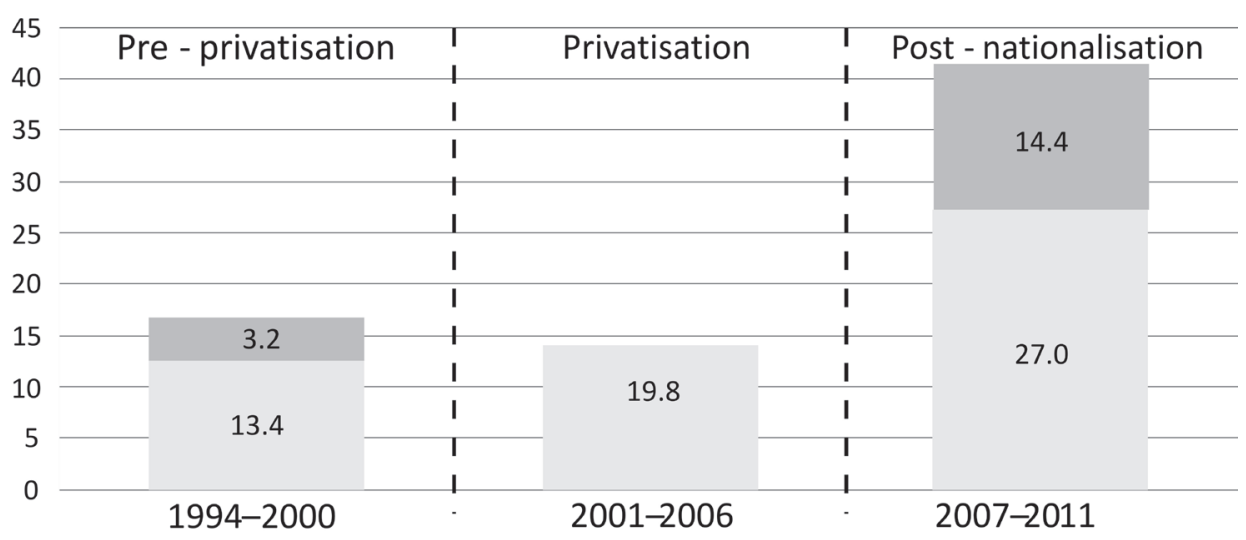

EVR own funds EU and state funds

Source: Koppel \& Archer, 2006; Communication with Estonian Railways, 2012

The aforementioned shows that the market in case of railway infrastructure management is seen as an oligopoly rather than a monopoly, that is a market where a limited number of sellers sell their products practically to an unlimited number of buyers (Koppel, 2006). To illustrate the above-said, let us view the Baltic rail transport market as one integral whole where infrastructure managers Estonian Railways (Estonia), LDz Infrastruktūra (Latvia) and LG Railway Infrastructure Directorate (Lithuania) compete with each other. As 
is shown in Figure 10, the volume of internationally moving freight hauled by the Baltic railways in 2006-2010 has varied by approximately 15 per cent and a significant role in the distribution of freight between the countries is played by the economic policy considerations of Russia, whereas in shortterm perspective the volume of freight going through the Baltic countries has been stable.

Figure 10. Volume of freight hauled by Baltic railways in 2006-2011

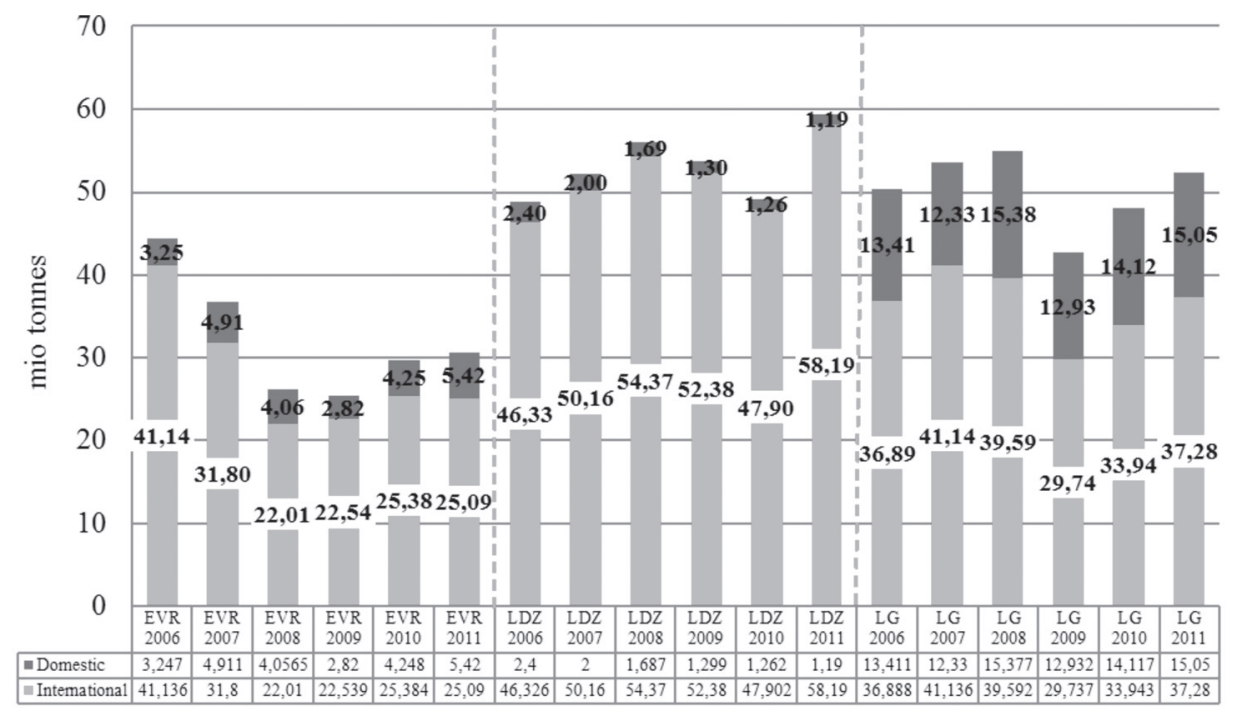

Source: Authors' illustration based on the information of Baltic railway undertakings

There are also opinions that the new railway directive aims at establishing more precise infrastructure charging rules in order to end the forced subsidising of passenger transport by freight transport in the CEE countries. For example, the railway infrastructure access fee calculation method employed in Estonia is known from the theory of economics as fully distributed costs (FDC) pricing method (see above).

Access fee is calculated as two-part tariff, using, in the authors' opinion, unjustifiably the assumption that 30 per cent of railway infrastructure management costs are fixed and 70 per cent are variable. Fixed costs are distributed between freight operators in accordance with the share of capacity allocated to a company (measured in train kilometres) and variable costs based on the mutual proportion of companies' rolling stock works (measured in gross tonne kilometres). The distinctive character of the Estonian system is that the companies providing public passenger transport services are exempt from 
paying the fixed cost component of railway infrastructure access fee that causes legitimate doubts about the existence of cross-subsidies (Koppel, 2006).

The element of cross-subsidising is present also in the infrastructure pricing mechanisms of other countries (see Figs. 11 and 12), whereas in Norway the passenger trains using railway infrastructure pay no fee whatsoever. There exists a rational explanation for that, as the pricing of road transport competing with railway infrastructure does not include full infrastructure and environmental costs. Meanwhile, there also exist cases where freight transport is cross-subsidised by passenger transport. This is mostly happening in some Nordic countries where the governments want to shift freight from road to rail. It is peculiar that freight transport subsidising by rail passenger transport funded from state budget is also happening in Estonia - on the railway infrastructure belonging to Edelaraudtee Infrastruktuuri AS (South-West Railway Infrastructure, Ltd).

Figure 11. Infrastructure access charges for freight and passenger trains in selected countries

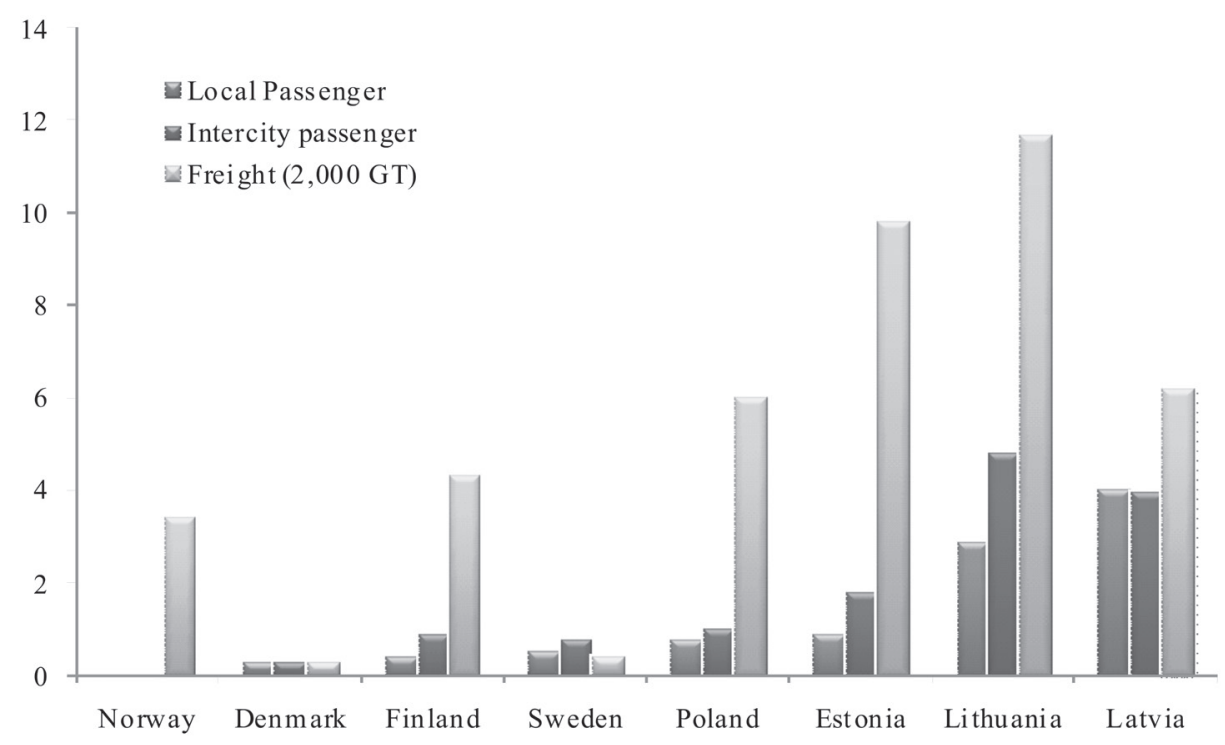

Source: Thompson, 2008

Based on the foregoing statements, the following conclusions can be drawn. The increasing volumes of rail freight transportation in the Baltic CEECs signify that "the market can bear the applied charges", as it is mentioned in the proposed new directive (Communication from..., 2010). Moreover, a specific feature of railway market in the Baltic States is that more than 70 per cent of freight traffic 
comes/goes from/to third countries (Russia, Belarus, etc.) and raw materials are the dominant type of freight. If the possibilities for the mentioned countries to recover total costs are to be limited then it would signify: a) unbearable burden for national budgets to invest in railways, and b) unjustified outcome of subsidising third countries. On the other hand, the market failures in unfair pricing of passenger and freight transport have to be eliminated.

Figure 12. Ratio of the access charge per a typical 2,000 gross tonne freight train to charge per a 590 gross tonne intercity passenger train

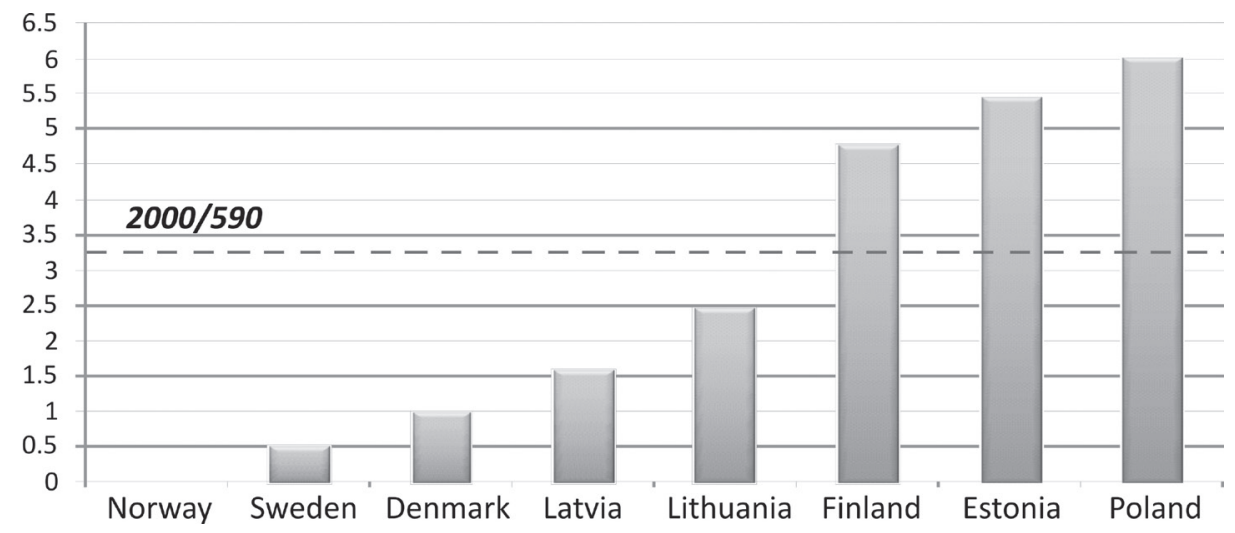

Source: Authors' calculation

\section{Conclusions}

The results of the research indicate that the organisation of rail transport in any CEE country located in the Baltic Sea region is not compliant with the respective legislation of the European Union and the compliance with those legislative acts would require certain reorganisation at the government agencies' level. The authors still doubt whether the establishment of an independent body only for the purpose of supervising competition on railways would be reasonable considering the small size of the Baltic States. Among other things it might appear necessary to transfer the shares of rail transport undertakings from holding companies to the governments or privatisation of companies. In other aspects, good reorganisation examples can be seen in the Nordic countries, particularly Denmark, where the legal (but not ownership) separation has already been completed.

Meanwhile, the Baltic States and Poland acceded to the EU in 2004. As such, neither Estonia, nor any other acceding Member State, had an opportunity to 
influence the First Railway Package, issued in 2001. Nevertheless, necessary exemptions were applied for and received by Finland. Now, during the recast of new railway directive there is an opportunity to make necessary amendments taking into account the particularities of the Baltic States. Possible solutions to the problem could comprise one or several of the following steps:

1) Apply for an exemption for the Baltic countries for using the fully distributed cost method for railway infrastructure pricing until the companies working on the rail transport market are able to pay it;

2) Stipulate that the requirements of the new EU railway directive will not apply to international rail transport from third countries;

3) Stipulate that the requirements of the new EU railway directive will not apply to international rail transport to the seaports of the Baltic countries.

4) Considering what has been said above, the authors are of the opinion that the recommendations given would ensure the sustainable development of railway business in the CEE countries located in the Baltic Sea region. These recommendations would actually facilitate and not hinder the achievement of the goals laid down in the EU documents dealing with development. This statement is also supported by the fact that at the time of writing the present article such ideas are being discussed also in the European Parliament (Serracchiani, 2011).

\section{References}

Baumstark, L. \& Bonnafous, A. (1998), 'User Charges for Railway Infrastructure,' CEMT/ECMT Conclusions of Round Table, no. 107, pp. 47-100.

CIA (2011), The World Factbook, Washington, D.C.: Central Intelligence Agency.

Communication from the Commission concerning the development of a Single European Railway Area (2010), COM(2010)474 final, Brussels, 17.09.2010.

Communication from the Commission concerning the European Union Strategy for the Baltic Sea Region (2009), COM(2009)0248 final, Brussels, 10.6.2009.

Deutsche Bahn (2011), Competition Report 2011, Berlin: Deutsche Bahn AG.

DG Mobility and Transport (2011), Length of TEN-T railways per country and link type,

[data file] Retrieved from http://ec.europa.eu/transport/infrastructure/networks eu/doc/rail_tab1_country_length_ten-t_rail.pdf [accessed 15 Sep 2012]

ECMT (2005), Railway Reform and Charges for the Use of Infrastructure, Paris:

European Conference of Ministers of Transport.

Estonian Railways (2012), Personal communication with representatives of Estonian Railways. 
EU (2011), EU Energy and Transport in Figures, Luxembourg: Publications Office of the European Union.

IBM (2011), Rail Liberalisation Index 2011. Market Opening: Rail Markets of the Member States of the European Union, Switzerland and Norway in comparison, Brussels: IBM Global Business Services.

ITF (2012), Infrastructure Investment and Maintenance Data 1992-2010 (2009): Rail [data file] Retrieved from http://www.internationaltransportforum.org/statistics/ investment/data.html [accessed 16 Sep 2012]

Koppel, O. (2006), Infrastructure accounting in Vertically Integrated Railways: Pricing Approach (Example of the Estonian main railway company), Unpublished Ph. D. thesis. Tallinn: Tallinn University of Technology.

Koppel, O. \& Archer, S. C. (2006), 'The need for investment in CEE Countries: the example of Estonia,' Paper presented at Adam Smith Institute's $11^{\text {th }}$ Annual Conference "The Future of European Rail", Berlin, Germany.

Kukke, M. (2011), 'Energiakontsernide lahutamine on vajalik,' [in Estonian; Separation of groups of companies dealing with energy is necessary] Raamatupidaja.ee, 6 May 2011.

Nežerenko, O. (2009), 'How can the EU Baltic Sea Strategy contribute to the recovery of cooperation in the field of transit (as exemplified by the cooperation of the Baltic States in the years 2004-2008),' Proceedings of the Institute for European Studies, Tallinn University of Technology, no. 6, pp. 50-66.

Nežerenko, O. \& Koppel, O. (2012), 'Problems in International Transport Arising from the Unbundling of Railway Companies in the Baltic States,' Paper presented at The $4^{\text {th }}$ International Conference "Economic Challenges in Enlarged Europe", 17-19 June 2012, Tallinn, Estonia.

OSJD (2002), Recommendations for the Rail Transport Statistics, Glossary, Warsaw: Organisation for Co-operation between Railways.

RGL Forensics (2009), Study on Separation of accounts of railway undertakings and rail infrastructure managers: Final report, RGL Forensics, Frontier Economics, and AECOM.

Serracchiani, D. (2011), Amendments 128-724, Report on the proposal for a directive (COM(2010)0475-C7-0268/2010-2010/0253(COD)), European Parliament, Committee on Transport and Tourism, 19 Oct 2011.

Thompson, L. S. (2009), Liberalization and commercialization of the world's railways: Progress and key regulatory issues, Forum Paper 6, International Transport Forum "Transport for a Global Economy: Challenges and Opportunities in the Downturn", Paris: OECD.

(2008), Railway Access Charges in the EU: Current Status and Developments Since 2004, Paris: OECD Publishing. 
UIC (2008), Railway time-series data 1970-2007, Paris: International Union of Railways, Statistics Centre.

White Paper (2011), Roadmap to a Single European Transport Area - Towards a competitive and resource efficient transport system: White paper, COM(2011)144 final, Brussels, 28.3.2011.

- (2001), European transport policy for 2010: time to decide: White Paper, $\operatorname{COM}(2001) 370$ final, Brussels, 12.9.2001.

Winsor, T. (2010), Effective Regulatory Institutions: The Regulator's Role in the Policy Process, including Issues of Regulatory Independence, OECD/ITF Joint Transport Research Centre Discussion Papers 2010/21, Paris: OECD Publishing. 